\title{
Studi Kasus Implementasi Layanan Pendidikan Inklusif di Kota Madiun
}

\author{
Halim Jaya Persada ${ }^{1}$, Mohammad Efendi \\ ${ }^{1}$ Sekolah Alam Afisiena Malang \\ ${ }^{2}$ Universitas Negeri Malang \\ Email: halimjaya9c07@gmail.com
}

\begin{abstract}
Abstrak: Tujuan dari penelitian ini adalah mendeskripsikan sejauhmana sekolah inklusif yang ada di Kota Madiun melaksanakan layanan pendidikan inklusif. Peneltian ini menggunakan metode kualitatif. Peneliti menggunakan observasi, wawancara dan dokumentasi dalam memperoleh data. Hasil yang didapat oleh peneliti adalah belum maksimalnya penyelenggraan layanan pendidikan inklusif di sekolah-sekolah inklusif di kota Madiun. Persepsi tentang pendidkan inklusif yang masih minim, Guru Pembimbing Khusus (GPK) belum ada, fasilitas penunjang belum terpenuhi, sampai peran Dinas Pendidikan Kota Madiun yang belum maksimal dalam mengelola terlaksananya layanan pendidikan ini. Berdasarkan hasil penelitian tersebut dapat disimpukan bahwa Kota Madiun belum siap secara maksimal dalam menyelenggarakan sekolah inklusif.
\end{abstract}

Kata Kunci: Pendidikan Inklusif; Sekolah Inklusif; Kota Madiun

\begin{abstract}
The purpose of this research is to describe how Madiun City implementing the inclusive education services. This research used the qualitative method. The reasercher used the observation, interview and documentation technique to collect the datas. The result was, the implementation of the inclusive education in Madiun City's inclusive school has not maximum. The perception of inclusive education was still minimum. The Special Guidance Teacher has not been provided yet. The facilities were not fulfill and the Education Council of Madiun City already yet to organized this education services yet.. The final conclusion is that the Madiun City has not already organized the inclusive school yet. Key Word: Inclusive Education, Inclusive School, Madiun City
\end{abstract}

Pendidikan termasuk diantara aspek terpenting dalam kehidupan seorang manusia, baik manusia tanpa kebutuhan khusus maupun manusia dengan kebutuhan khusus. Menurut Undang-undang No. 20 tahun 2003 "mengenai Sistem Pendidikan Nasional, pendidikan merupakan bentuk usaha sadar dan terencana didalam mewujudkan suasana belajar dan proses pembelajaran agar peserta didik secara aktif mengembangkan potensi dirinya untuk memperoleh kekuatan spiritual keagamaan, akhlak mulia, pengendalian diri, kepribadian, kecerdasan, serta keterampilan yang diperlukan dirinya, masyarakat, bangsa, dan negara". Pendidikan harus diberikan kepada semua kalangan, baik dari penyandang hambatan intelektual ataupun penyandang hambatan fisik tidak hanya diberikan kepada manusia reguler. Termaktub dalam ayat 1, Pasal 5 UU no. 20 tahun 2003 tentang Sisdiknas yakni, " setiap warga negara mempunyai hak yang sama untuk memperoleh pendidikan yang bermutu". Dilanjutkan dengan ayat 2 Pasal 5 UU no. 20 tahun 2003 tentang Sisdiknas, yakni "warga negara yang mempunyai kelainan fisik, emosional, mental, intelektual, dan/atau sosial berhak memperoleh pendidikan khusus". Dari situlah dicetuskan sebuah sistem pendidikan yang dikenal sebagai pendidikan inklusif. Menurut Permendiknas Nomor 70 Tahun 2009 menyebutkan, pendidikan inklusif merupakan "sistem penyelenggaraan pendidikan yang memberikan kesempatan kepada semua peserta didik yang memiliki kelainan dan memiliki pontensi kecerdasan dan/atau bakat istimewa untuk mengikuti pendidikan atau pembelajaran dalam lingkungan pendidikan secara bersama-sama dengan peserta didik pada umumnya".

Ilahi (2013) menyatakan bahwa "pendidikan inklusif didefinisikan sebagai bentuk konsep yang menampung semua anak berkebutuhan khusus ataupun anak yang memiliki kesulitan menulis dan membaca". Berkesinambungan dengan pernyataan diatas, seperti yang diungkapkan oleh Ummah, 2017) Quality of education process would gain maximum results and relevant to the development of human being. Selain itu menurut Hermanto (2015) juga menyatakan dalam bukunya, "pendidikan inklusif adalah sistem pembelajaran yang menghadirkan individu berkebutuhan khusus sebagai bagian dalam proses pembelajaran dan mendapatkan kesempatan belajar di sekolah reguler. Selain itu, sekolah inklusif harus menghargai keberagaman peserta didik, dengan memberikan layanan yang tepat sebagaimana kondisi dan kebutuhannya, serta pendidikan inklusif juga memposisikan peserta didik berkebutuhan khusus agar dapat mengakses kebutuhan belajar di sekolah terdekat".

Berdadsarkan studi pendahuluan yang dilakukan peneliti di tahap awal, ditemukan fakta, bahwa Kota Madiun merupakan sebuah kota yang berada di sebelah 
barat Provinsi Jawa Timur, telah merealisasikan layanan pendidikan inklusif sebagaimana kotakota lainnya di Provinsi Jawa Timur. Hal ini dapat dibuktikan dengan telah diterbitkanya Surat Keputusan Kepala Dinas Pendidikan Kota Madiun Nomor Nomor: 420-401.104/2354/2013 tentang Penyelenggaraan Pendidikan Inklusif di Kota Madiun. Namun, terlihat sekali layanan pendidikan inklusif yang bisa dibilang tidak maksimal di dalam pelaksanaannya. Banyak kekurangan yang terlihat di sekolah sekolah-sekolah inklusif tunjukan Dinas Pendidkan Kota Madiun.

Diadakannya penelitian ini untuk mendeskripsikan gambaran tentang kesiapan Kota Madiun dalam menyelenggarakan sekolah inklusif. Fokus pertama yang dilihat oleh peneliti adalah tentang persepsi sekolah inklusi yang ditunjuk oleh Dinas Pendidikan Kota Madiun dalam penyelenggaraan sekolah Inklusif. Fokus kedua adalah kendala oleh sekolah inklusif di Kota Madiun selama ini dalam menyelenggrakan layanan pendidikan inklusif. Terakhir, fokus ke tiga adalah tentang kesiapan ari sekolah-sekolah inklusif di kota tersebut, apabila sekolah mereka dijadikan sekolah inklusif secara berkelanjutan atau permanen.

\section{METODE}

Penelitian ini menggunakan metode kualitatif. Metode ini digunakan oleh peneliti karena peneliti ingin mengetahui implementasi layanan pendidikan inklusif di Kota Madiun secara maksimal. Maka dari itu, peneliti menggunakan kaidah atau teknik pengumpulan data yang digunakan, yakni dengan menggunakan wawancara, observasi dan dokumentasi. Adapaun sekolah yang menjadi objek tempat penelitian ini ada 5 sekolah inklusif di jenjang sekolah dasar dan sekolah menengah pertama, yakni SDN 02 Winongo, SDN 02 Taman, SMP Negeri 8 Madiun, SMP Negeri 9 Madiun dan SMP Negeri 10 Madiun. Metode analisis data yang digunakan pada penelitian ini mengacu pada metode analisis yang dikembangkan oleh Miles dan Huberman. Model ini menggunakan 3 tahap, yakni, data reduction (reduksi data), data display (penyajian data), dan conclusion drawing (verifikasi). Pengecekan keabsahan temuan data pada penelitian ini menggunakan trangulasi, yakni triangulasi sumber dan triangulasi teknik.

\section{HASIL DAN PEMBAHASAN}

\section{Hasil}

Persepsi tentang Sekolah Inklusif Pada penelitian ini sekolah-sekolah yang menjadi subjek penelitian terlihat sudah memahami apa itu yang dimaksud dengan pendidikan inklusif dan sekolah inklusif. Mereka mempersepsikan sekolah inklusif merupakan sekolah yang menyelenggarakan pendidikan bagi anak- anak berkebutuhan khusus dengan anak-anak yang reguler atau dengan kata lain anak-anak normal. Pada masing-masing sekolah baik dasar maupun menengah pertama tersebut sudah memiliki siswa berkebutuhan khusus dengan berbagai jenis ketunaan, seperti autis, lambat belajar, kesulitan belajar, ADHD, indigo, Down Syndrome, tunarungu, dan tunanetra kategori Low Vision. Saat ini siswa berkebutuhan khusus yang mendominasi di sekolah inklusif Kota Madiun adalah Autis dan lambat belajar.

Selama penelitian berlangsung peneliti juga melihat keadaan pelaksanaan pendidikan inklusif yang terkesan biasa-biasa saja, bahkan dalam penerimaan peserta didik baru, sekolah tidak melaksanakan identifikasi atau asesmen. Sekolah hanya menerima murid saja, apabila itu murid berkebutuhan khusus, karena sudah merasa menjadi tugas yang diberikan oleh Dinas Pendidikan Kota Madiun, sekolah tetap menerima murid baru tersebut.

Kendala yang Dihadapi Pada penelitian ini ditemukan kendala yang mana kendala tersebut merupakan kendala utama yang dirasakan oleh sekolahsekolah inklusif di Kota Madiun selama ini. Kendala pertama adalah kurangnya tenaga kependidikan khusus atau biasa disebut dengan Guru Pembimbing Khusus (GPK). Sekolah inklusif yang seharusnya memiliki guru pendamping khusus yang tugasnya untuk mendampingi siswa dengan kebutuhan khusus dalam pembelajarannya ini, belum bisa disediakan oleh Dinas Pendidikan selaku induk penyelenggara pendidikan di Kota Madiun. Peran GPK yang ada disekolah akhirnya digantikan oleh guru-guru sendiri dalam hal ini guru kelas atau bisa juga orang tua yang menjadi pendamping khusus siswa berkebutuhan khusus saat berada dalam kegiatan pembelajaran. Hal ini sangat ironi sekali, dimana yang seharusnya sekolah dengan label inklusif mempunyai tenaga pendidikan yang khusus untuk siswa berkebutuhan khusus ini malah tidak tersedia.

Kendala yang ke dua adalah fasilitias penunjang sekolah inklusif yang belum memadai. Bisa dilihat di sekolah, bahwa sekolah inklusif yang seharusnya memiliki beberapa fasilitas khusus seperti ruang sumber dan media pembelajaran adaptif, hal ini malah belum terpenuhi. Di ruang sumber, siswa berkebutuhan khusus bisa melakukan kegitan pembelajaran, tambahan belajar, konsultasi akademik bersama Guru Pembimbing Khususnya. Selain itu fungsi lain dari ruangan ini adalah sebagai sentra atau pusat layanan pendidikan inklusif di sekolah. Bantuan berupa dana pendidikan untuk peleksanaan layanan pendidikan inlusif juga belum ada. Alasan yang kuat tentang kurang maksimalnya perhatian untuk sekolah inklusif ini adalah SK pelaksanaan sekolah inklusif yahg masih tertandatangani oleh kepala dinas, bukan kepala daerah (walikota), jadi, untuk pengajuan bantuan tenaga kependidikan khusus dan pemenuhan fasiltas sarana dan prasarana sekolah inklusif belum bisa dilaksanakan 
secara resmi. Hal ini juga ironis, karena sekolah dengan label inklusif belum difasilitasi dengan fasilitas sarana dan prasarana yang menunjang kegiatan belajar mengajar di sekolah inklusif.

Kesiapan Sekolah dalam Pelaksanaan Layanan pendidikan Inklusif Terlepas dari kendala yang dirasakan oleh masing-masing sekolah dasar inklusif tersebut, layanan pendidikan inklusif di masingmasing sekolah dasar tersebut akan terus dilaksanakan. Masing-masing sekolah telah berdapat bahwa meraka akan siap apabila sekolah mereka menerapka layanan pendidikan inklusif secara berkelanjutan. Harapan yang diinginkan oleh sekolah inklusif Kota Madiun adalah Dinas Pendidikan Kota Madiun bisa memaksimalkan pelaksanaan sekolah dasar inklusif. Memberikan perhatian lebih kepada sekola-sekolah tersebut dalam pelaknaan layanan pendidika inklusif dan bisa menaggulangi kendala-kendala yang dihadapi oleh sekolah dasar inklusif Kota Madiun.

\section{Pembahasan}

Persepsi tentang Sekolah Inklusif Peneliti telah melaksanakan penelitian di 5 sekolah inklusif tunjukan dari Dinas Pendidikan Kota Madiun, yakni SD Negeri 02 Winongo, SD Negeri 02 Taman, SMP Negeri 8 Madiun, SMP Negeri 9 Madiun dan SMP Negeri 10 Madiun. Peneliti menanyakan tentang persepsi dari sekolah-sekolah tersebut tentang sekolah atau pendidikan inklusif. Peneliti dapat menyimpulkan bahwa pendidikan inklusif merupakan suatu layanan yang tidak menbeda-bedakan peserta didik baik yang reguler maupun berkebutuhan khusus dalam menempuh pendidikan agar hak asasinya tercapai, yakni hak akan mendapatkan pendidikan.

Hal ini sependapat dengan beberapa perrnyataan yang dikemukakan oleh beberapa ahli pendidikan inklusif atau pendidikan khusus. Rachmanayana (2013) mengutarakan bahwa "pendidikan inklusif adalah sistem layanan pendidikan berupa pemberian kesempatan belajar bersama-sama di sekolah umum kepada seluruhanak, denganmemperhatikankeragaman dan kebutuhan individual, sehingga secara optimal potensi anak dapat berkembang. Selain itu, Garnida (2015) menyatakan pula prihal pendidikan inklusif, sebagaimana "merupakan sistem penyelenggaraan pendidikan bagi anak-anak yang memiliki keterbatasan tertentu dan anak-anak lainnya yang disatukan dengan tanpa mempertimbangkan keterbatasan masingmasing". Pada Proceeding ICSAR $7^{\text {th }}$ 2017, Yuwono (2017) juga mengutarakan bahwa sekolah inklusif merupakan sekolah yang menciptakan pembelajaran yang ramah bagi semua peserta didik, baik reguler maupun anak berkebutuhan khusus, sehingga sekolah tidak membeda-bedakan peserta didik, semua siswa berhak mendapatkan layanan pendidikan yang sama.

Jadi dapat simpulkan bahwa pendidikan inklusif merupakan suatu layanan pendidikan yang bersifat education for all, atau dalam bahasa Indoneisa disebut pendidikan untuk semua, dimana sistem pendidikan ini tidak melihat kondisi siswa baik yang reguler maupun berkebutuhan khusus untuk belajar secara bersamasama di sekolah reguler.

Kendala yang Dihadapi Sekolah Inklusif di Kota Madiun Ada 2 (dua) hal yang menjadi kendala terbesar dalam pelaksanaan layanan pendidikan inklusif di Kota Madiun, yakni tenaga kependidikan khusus yang menjadi Guru Pembimbing Khusus (GPK) dan masalah fasilitas atau biasa disebut dengan sarana dan prasarana.

Guru Pembimbing Khusus (GPK) yang ada saat ini di sekolah-sekolah inklusif di Kota Madiun belum ada. Siswa berkebutuhan khusus yang bersekolah di sekolah inklusif memiliki pendamping sendiri, yakni orang tuanya sendiri atau biasanya siswa didampingi oleh saudaranya (tante, kakak, paman, dll) dan apabila orang tua siswa mampu dalam keuangan mereka akan menyewa seorang shadow teacher.

Guru Pembimbing Khusus adalah sesuatu yang penting dan mutlak harus dimiliki oleh sekolah penyelenggra pendidikan inklusif. Hal ini diutarakan oleh Ilahi (2013) yang mana faktor penentu keberhasilan pendidikan inklusif yang tak kalah pentingnya adalah tenaga pendidik yang profesional dalam bidangnya (Pendidikan Khusus). Tidak adanya guru yang memiliki kompetensi yang khusus dalam bidang pendidikan khusus menyebabkan sekolah inklusif akan merasa kesulitan dalam melaksanakan layanan pendidikan inklusif di sekolahnya. Hal ini dikarenakan Guru Pembimbing Khusus inilah yang membuat, memodifikasi kurikulum atau rencana belajar siswa sampai pembuatan PPI (Program Pembelajaran Individual) bagi siswa berkebutuhan khusus di sekolah inklusif.

Selain itu juga dikatakan bahwa guru-guru yang ditempatkan pada pendidikan inklusif mesti memiliki penguasaan akan fungsi dan tugas yang lebih dibandingkan dengan guru pendidikan biasa (Mudjito, dkk, 2012). Efendi (2016) juga menerangkan bahwa tugas Guru Pembimbing Khusus adalah sebagi berikut. (1) Menyusun instrument asesmen pendidikan bersama-bersama dengan guru kelas dan guru mata pelajaran. (2) Membangun sistem koordinasi antar guru, pihak sekolah dengan orang tua siswa. (3) Memberikan bimbingan kepada anak berkalainan, sehingga anak mampu mengatasi hambatan atau kesulitan dalam belajar. (4) Memberikan bantuan (sharing pengalaman) kepada guru kelas dan/atau guru mata pelajaran agar mereka dapat memberikan pelayanan pendidikan khusus kepada anak luar biasa yang membutuhkan.

Selanjutnya kendala pada sarana dan prasarana. Kita semua tahu, bahwa sarana dan prasaran merupakan 
sesuatu hal yang sangat strategis untuk menunjang jalannya pembelajaran pada sekolah, terlebih lagi dengan sekolah yang berlabel sekolah penyelenggara layanan pendidikan inklusif. Wahyuningrum (2004, dalam Ilahi, 2013) mengutarakan bahwa "sarana-prasarana adalah segala sesuatu yang dapat memudahkan pelaksanaan suatu kegiatan". Terlebih lagi kegitan itu adalah kegiatan pembelajaran siswa di sekolah. Pada sekolah inklusif sarana yang perlu ada dan harus ada di sekolah inklusif salah satunya dalah ruang sumber atau ruang sentra inklusi dari sekolah inklusi. Di ruang atau kelas ini siswa ABK pada sekolah inklusif bisa lebih mengeksplorasi potensi baik dari potensi akademik maupun potensi non-akademik. Dibidang akademik, siswa berkebutuhan khusus dapat melakukan tambahan belajar dengan Guru Pembimbing Khususnya. Di ruang inilah siswa akan melaksanakan pembelajaran yang menggunakan teknik, strategi dan pendekatan pembelajaran yang berdeda dengan kelas regular. Kemudian, di bidang non akademik, di ruang ini siswa bisa mengembangkan bakat dan minat mereka, seperti dibidang seni. Tidak heran apabila biasanya di ruang sumber ini terdapat banyak hasil karya siswa berkebutuhan khusus yang dipajang di diding ruang sumber ini. Maka dari itu pemerintah harusnya lebih peka dalam menyelenggarakan sekolah inklusif ini.

Kesiapan Sekolah-sekolah Inklusif di Kota Madiun dalam Penyelenggraan Pendidikan Inklusif Lebih Lanjut Sekolah inklusif yang bisa dikatakan benar-benar sebagai penyelenggara layanan pendidikan inklusif adalah sekolah yang telah memenuhi syaratsyarat yang harus dipenuhi dalam penyelenggraan pendidikan inklusif. Berikut hal-hal yang harus diperhatikan dalam penyelenggraan pendidikan Inklusif menurut Permendiknas Nomor 70 Tahun 2009. (1) Sekolah harus menyediakan kondisi kelas yang hangat, ramah, menerima keanekaragaman dan menghargai perbedaan. Sekolah harus siap dalam mengelola kelas yang heterogen dengan menerapkan kurikulum dan pembelajarn yang bersifat individual. Guru harus menerapkan pembelajaran yang interaktif. (2) Guru dituntut melakukan kolaborasi dengan profesi atau sumber daya lain dalam perencanaan, pelaksnaan, dan evaluasi. (3) Guru dituntut untuk melibatkan orang tua secara bermakna dalam proses pendidikan. (4) Kepala sekolah dan guru (yang nantinya akan menjadi GPK) harus mendapatkan pelatihan bagaimana menjalankan sekolah inklusif. (5) GPK mendapatkan pelatihan teknis menfasilitasi anak ABK. (6) Asesmen di sekolah dilakukan untuk mengetahui anak ABK dan tindakan yang diperlukan. Mengadakan bimbingan khusus atas kesepahaman dan kesepakatan dengan orang tua ABK. (7) Mengidentifikasi hambatan berkaitan dengan kelainan fisik, sosial, dan masalah lainnya terhadap akses dan pembelajaran. (8) Melibatkan masyarakat dalam melakukan perencanaan dan monitoring mutu pendidikan bagi semua anak.
Sejalan dengan Permendiknas tersebut, menurut Kustawan (2012), yang dikutip oleh Khoirunnisa (2017) pada Proceeding ICSAR $7^{\text {th }}$ 2017, menyatakan bahwa, "ada pun sekolah yang mengimplementasikan pendidikan inklusif harus memenuhi beberapa persyaratan berikut ini. (1) Telah memiliki ijin operasional dari Pemerintah Kabupaten/Kota; (2) Mampu merancang dan menggunakan kurikulum fleksibel; (3) Tersedia pendidik dan tenaga kependidikan yang memiliki kualifikasi akademik dan kompetensi yang sesuai dengan prosedur operasi standar; (4) Tersedia sarana dan prasarana pendidikan yang sesuai dengan prosedur operasi standar; (5) Tersedia sumber dana tetap yang menjamin kelangsungan penyelenggaraan pendidikan dan tidak merugikan peserta didik; (6) Mendapat rekomendasi penetapan sebagai sekolah penyelenggara pendidikan inklusif dari pemerintah Kabupaten/Kota dan ditetapkan sebagai sekolah penyelenggara pendidikan inklusif dari Pemerintah Provinsi. (Persyaratan nomor 6 ini berkaitan erat dengan fasilitas atau dukungan dana atau sarana dan prasarana yang diberikan oleh Pemerintah Provinsi dan Pemerintah dalam penyelenggaraan pendidikan inklusif)".

Melihat kenyataan di lapangan, pada sekolahsekolah inklusif di Kota Madiun belum menunjukkan hal-hal yang telah disebutkan pada Permendiknas di atas. Hal ini menyebabkan kurang siapnya sekolah dalam melaksanakan layanan pendidikan inklusif di sekolah mereka. Sekolah inklusif harus memiliki tenaga pendidik khusus atau yang disebut dengan GPK. Namun kenyataan di sekolah-sekolah inklusif di Kota Madiun belum memilikinya sama sekali. Inilah yang menyebabkan sekolah belum siap untuk melaksanakan layanan pendidikan inklusif secara maksimal.

Preposisi setelah penelitian dilakukan, peneliti menyatakan proposisi sebagai berikut. Apabila seluruh sekolah inklusif di Kota Madiun mendapatkan pelatihan tentang pendidikan inklusif, maka sekolah inklusif di Kota Madiun akan memahami penuh tentang pelaksanaan layanan pendidikan inklusif. Apabila kendala-kendala yang di hadapi oleh sekolahsekolah inklusif di Kota Madiun teratasi, maka layanan pendidikan inkusif di sekolah-sekolah inklusif akan berjalan secara baik dan benar. Apabila sekolah-sekolah inklusif sudah menyatakan siap dalam melaksanakan layanan pendidikan inklusif, maka seharusnya Dinas Pendidikan Kota Madiun harus memperhatikan layanan pendidikan inklusif yang terselenggara dan segera melakukan pemenuhan fasilitas-fasilitas yang dibutuhkan oleh sekolah inklusif.

Jadi, dapat disimpulkan bahwa, apabila dalam pelaksanaan layanan pendidikan inklusif Kota Madiun diperhatikan secara maksimal oleh Dinas Pendidikan Kota Madiun, maka layanan pendidikan inklusif yang ada di sekolah-sekolah inklusif Kota Madiun akan berjalan dengan benar sesuai aturan yang berlaku. 


\section{KESIMPULAN DAN SARAN}

\section{Kesimpulan}

Setelah diadakan penelitian yang melibatkan sekolah-sekolah inklusif tunjukan Dinas Pendidikan Kota Madiun, peneliti dapat menyimpulkan bahwa, Kota Madiun belum siap untuk menyelenggarakan sekolah inklusif. Namun, terlepas dari kendala-kendala yang dirasakan, para kepala sekolah dan guru-guru sekolah-sekolah inklusif tersebut sudah sedikit paham apa yang dimaksud dengan sekolah atau pendidikan inklusif, apa yang harus dilakukan dan apa yang harus diupayakan dalam rangka terselenggaranya sekolah inklusif atau layanan pendidikan inklusif secara maksimal di masing-masing sekolah mereka. Pihak sekolah-sekolah inklusif tersebut juga berpendapat bahwa apabila sekolah inklusif di Kota Madiun ini berlanjut penyelenggaraannya, mereka siap untuk menjadi sekolah perintis yang menerapkan layanan pendidikan inklusif.

\section{Saran}

Saran peneliti untuk keberlangsungan sekolah inklusif di Kota Madiun adalah maksimalkan peran Dinas Pendidikan Kota Madiun dalam pelaksanaan sekolah Inklusif. Beri kepastian sekolah-sekolah inklusif tentang Surat Keterangan penyelenggaraan pendidikan inklusif di Kota Madiun, karena dibeberpa sekolah tidak tahu kalau ada SK tentang penyelenggaraan sekolah inklusif di Kota Madiun. Lakukan sosialisasi tentang keinklusifan kapada warga masyarakat Kota Madiun dan segera memberikan fasilitas-fasilitas penunjang sekolah inklusif, mulai perumusan dari sistem penerimaan siswa berkebuthan khusus untuk sekolah inklusif, tenaga kerja atau SDM yang mempunyai keilmuan dibidang keinklusifan, kegitan-kegitan yang dapat menambah ilmu tentang keinklusifan dan bantuan untuk sarana dan prasaran sekolah inklusif. Saran tambahan dari peneliti, mungkin Dinas Pendidikan Kota Madiun bisa bekerja sama dengan Tim Pengembang Pendidikan Inklusif Provinsi Jawa Timur atau yang disingkat TP2I Jatim.

\section{DAFTAR RUJUKAN}

Nasional, P. M. P., \& INDONESIA, R. (2009). Pendidikan Inklusif bagi Peserta Didik yang Memiliki Kelainan dan Memiliki Potensi Kecerdasan dan/atau Bakat Istimewa.

Garnida, D. (2015). Pengantar Pendidikan Inklusif. Bandung: Refika Aditama.

Hermanto. (2015). Panduan untuk Kepala Sekolah Supervisi Pembelajran Sekolah Dasar Inklusif (Buku 1). Malang: Program Studi Manajeman Pendidikan Pascasarjana UM
Ilahi, M. T. (2013). Pendidikan inklusif: konsep dan aplikasi. Yogyakarta: Ar-Ruzz Media.

Khoirunnisa, K. (2017). Kurikulum Untuk Anak Berkebutuhan Khusus di Sekolah Inklusif. Prociding International Conference on Special Education in Southeast Asia Region (ICSAR) 7th 2017: Reorientation of Special Education in Improving Self-help of Children with Special Needs: Faculty of Education State University of Malang. (hlm. 73-79)

Mudjito. (2012). Pendidikan Inklusif (Wardi, Ed). Jakarta: Baduose media Jakarta

Mudjito. (2013). Berbagai Peraturan Pendidikan Khusus dan Layanan Khusus. Direktorat Pembinaan Pendidikan Dasar, Direktorat Jendral Pendidikan Dasar, Kementerian Pendidikan dan Kebudayaan

Rachmayana, D. (2013). Diantara Pendidikan Luar Biasa Menuju Anak Masa Depan Yang Inklusif. Jakarta: PT LUXIMA METRO MEDIA.

Yuwono, I. (2017). Evaluasi Pelaksnaan Program Pendidikan Inklusif SD di Kota Banjarmasin. International Conference on Special Education in Southeast Asia Region (ICSAR) 7th 2017: Reorientation of Special Education in Improving Self-help of Children with Special Needs: Faculty of Education State University of Malang. (hlm. 545-548) 